\title{
An Assessment of Public Perception of Police Response to Crime and Criminality in Anambra State of Nigeria
}

\author{
Onyeyilichukwu Onwuama $^{1^{*}}$ Ngozi Asadu $^{1}$ Precious Eke $^{1} \quad$ Miriam Egbuche $^{1}$ Obinna Nwoke ${ }^{1}$ \\ 1. Department of Sociology/Anthropology, University of Nigeria, Nsukka, Enugu State \\ * E-mail of the corresponding author: onyeyilichukwu.onwuama@unn.edu.ng
}

\begin{abstract}
Security of life and property in Nigeria is seriously deteriorating. The members of the public live in fear and have become increasingly uncertain about their safety and security. In recent years, there has been an upsurge in armed robbery, kidnapping, armed militancy, among others, with the police always 'talking tough' but doing little or nothing. This paper focused on the perception of the public on police response to crime cases in Anambra state of Nigeria. Cross sectional survey research design was adopted for the study. Simple random sampling technique was used to select four communities in the state. Purposive sampling technique was also used to select 624 respondents aged 18 years and above while structured questionnaire became the instrument for data collection. Descriptive statistics was employed for data analysis. Findings from the study show that educational attainment of respondents affected their rating of police effort in crime control $(\mathrm{p}=0.018)$; place of residence (urban/rural) affected people's perception on the promptness of the police to emergency cases $(\mathrm{p}=0.000)$. Further, sex of respondents was found not to be statistically significant with their perception on police-public partnership in crime control in Anambra state. The study therefore recommends formulation and implementation of policies to restructure and reposition the police force to respond adequately to crime.
\end{abstract}

Keywords: Perception, Public, Crime, Crime control/prevention, Police

DOI: $10.7176 / \mathrm{DCS} / 9-3-10$

Publication date:March $31^{\text {st }} 2019$

\section{Introduction}

Over three decades ago, Odekunle (1977) as cited by Igbo (2007) had claimed that Nigeria had a 'crime-problem' in which crime had become systematic, prevalent and highly organized, with all sectors and sections of the citizens getting involved, while the police efforts had yielded little or no results (p.148). Alemika (2012) concurred with this viewpoint when he said that Nigeria is suffering from a growing crime-problem, which is progressively threatening its sovereignty, security and development.

Today, the crime problem has even worsened and become more rampant, with incessant kidnapping, armed robbery and political killings in the south east and other parts of Nigeria, particularly Anambra State. Terrorist and suicide bombings in Northern Nigeria by an Islamic sect called 'Boko Haram' have also become the order of the day. Unprecedentedly, criminals now move in groups of ten, twenty, thirty and even fifty, thus painting a picture of fear, and helplessness to the public, even to the law enforcement agents. Very often, they achieve their purpose with little or no counter measures from law enforcement agents. Furthermore, unlike before, crime takes place more frequently "in-season and out-of-season", regardless of the time of the day. In other words, more than before, crime now happens in broad day light with the criminals being relaxed and in a lighter mood, even under the nose of the security agents (Anyanwu, Madubueze \& Onwuchekwa, 2010). Cases abound, to mention but a few, the most recent invasion of five banks by armed robbers at Offa, Kwara State killing scores of residents, including policemen, bank workers and passersby on April 5, 2018 (Ugwuanyi, 2018) and the one hundred and ten (110) Dapchi School Girls' Abduction on February 19, 2018 by Boko Haram (an extremist, Islamic, terrorist organization based in northeastern Nigeria) from Government Girls' Science and Technical College (GGSTC), Dapchi, Yobe State (Adekunle, 2018), all in Nigeria. Recall that on the night of 14-15 April, 2014, 276 female students were kidnapped from the Government Secondary School in the town of Chibok in Borno State, Nigeria and responsibility for the dastardly act claimed by the same Boko Haram terrorist group (Kola \& Ajakaye, 2018). The upsurge in crime appears to bother on the ineffectiveness and inefficiency of the police whose statutory duties revolve around crime control. Oputa (1975) as cited by Igbo (2007) defined crime control as:

'all efforts and activities designed to hold the volume of crime in effective check, to keep it from spreading, to restrict and prevent crime infection and contamination, to prevent crime from breaking and spreading to 
new areas, and to protect society against the activities of habitual and abnormal offenders.' (p.177)

For Dodsworth (2007), crime control is generally seen as a humane alternative to the punishment of an offence after it has been committed and is often understood as fundamental to liberal democracy. He argued that crime prevention is inextricably interwoven with the police and maintained that Fielding (1988a) and Colquhoun (1969) were the brains behind associating the police with crime prevention. In other words, the idea of crime prevention by the police developed in their work. Dambazau (2007) upheld this assertion when he submitted that prevention, as the basis of policing, was first formulated in England with the passage of the Metropolitan Police Act of 1829. He maintained that crime prevention was the primary goal of the organized police force before it was later overshadowed by emphasis on investigation, arrest and punishment. However, the idea of prevention of crime by the police assumed importance again in the early 1970's. Equally, he defined crime prevention as:

'a pattern of attitudes and behaviors directed at reducing the threat of crime and enhancing the sense of safety and security to positively influence the quality of life [...] and to develop environments where crime cannot flourish.' (p.234)

By implication, crime control is all-embracing, encompassing all known mechanisms or strategies that can help eradicate or at least reduce to the barest minimum, the incidence of crime and criminality.

The picture painted by the increase in crime is that the police are weak, incompetent and irrelevant to their principal mission - maintenance of order and enforcement of the laws (Ajayi, 2014). The police on their own part maintain that they are doing their utmost best to arrest the crime problem. They attribute their seeming incompetence in crime control to some factors such as the use of archaic and outdated equipment, that is, lack of modern and sophisticated equipment, inadequacy of information resulting from lack of public cooperation, poor training curriculum far below and incommensurate with the organized and scientific nature of crimes, poor welfare and salary packages of workers culminating in low incentive and interest to work, etc. The position of the police in the face of the crime menace notwithstanding, there is a great expectation of the people on them as maintainers of law and order, the gatekeepers of the criminal justice system and the foremost state agency in the fight against crime and criminals (Dambazau, 2007; Igbo, 2009).

Anambra State, the area where this work is domiciled, has her large share of Nigeria's crime problem. There have been cases of murder, abduction, armed robbery, rape, theft, etc. in a terrifying and incredible manner in different parts of the state. An instance is a robbery attack on three banks in Ihiala town in the Ihiala Local Government area of Anambra State (Anyanwu, Madubueze \& Onwuchekwa, 2010) and uninterrupted armed robbery attack on the Nigerian Television Authority (NTA), Awka station on the 1st of March, 2008 from 1:00am till 4:30am without the intervention of the police (Nnaji, 2008). However, the security agencies including the Police, Army, Prisons, among others, have a "fair share" of the criminal victimization as either their barracks, stations or convoys have been attacked severally in different parts of the country. For instance, Amichi Police Station in Nnewi South Local Government Area was attacked and sacked by gunmen who made away with fourteen (14) AK 47 rifles after freeing the detainees, and leaving a policeman seriously injured on April 4, 2012 (Anyanwu \& Onuorah, 2012). This same source revealed that earlier, at about 7pm on Tuesday, April 3, 2012 another gang of gunmen stormed the ever-busy Aroma junction, Awka, in a bid to kidnap a man whose identity was yet to be known. Unimaginably, a day after the Amichi incidence, gunmen suspected to be armed robbers stormed Ukpor Police Station in the same Nnewi South Council Area of Anambra State, killing three mobile police men and setting the station ablaze. They also carted away an undisclosed number of AK 47 rifles (Onuora \& Ekpunobi, 2012).

Official crime statistics obtained from Nigeria Police Force, Awka, indicate that most of the crimes showed a remarkable upsurge between 2005 and 2010. Table 1 below shows the official 
Table I: Anambra State Crime Statistics from 2005 - 2010

\begin{tabular}{|l|l|l|l|l|l|l|l|l|l|l|}
\hline Year & Robbery & Murder & Burglary & $\begin{array}{l}\text { House } \\
\text { Breaking }\end{array}$ & $\begin{array}{l}\text { Theft \& } \\
\text { Other } \\
\text { Stealing }\end{array}$ & Kidnapping & $\begin{array}{l}\text { Child } \\
\text { Stealing }\end{array}$ & Arson & Rape & Total \\
\hline 2005 & 29 & 16 & 47 & 46 & 528 & 5 & 4 & 12 & 22 & $\mathbf{7 0 9}$ \\
\hline 2006 & 74 & 41 & 114 & 49 & 608 & 16 & 2 & 21 & 70 & $\mathbf{9 9 5}$ \\
\hline 2007 & 96 & 50 & 40 & 46 & 625 & 6 & 7 & 20 & 24 & $\mathbf{9 1 4}$ \\
\hline 2008 & 30 & 20 & 21 & 18 & 47 & 10 & 3 & 13 & 7 & $\mathbf{1 6 9}$ \\
\hline 2009 & 255 & 120 & 100 & 82 & 720 & 132 & 18 & 17 & 115 & $\mathbf{1 5 5 9}$ \\
\hline 2010 & 103 & 56 & 77 & 91 & 209 & 130 & 36 & 41 & 59 & $\mathbf{8 0 2}$ \\
\hline
\end{tabular}

Source: Nigeria Police Force, Anambra State Headquarters, Awka.

crime statistics of Anambra State from the year 2005 to 2010. Noticeably, there was a remarkable decrease in crime in 2008 in Anambra State and this skyrocketed in the following year 2009. Obviously, the year 2009 was deadly in the state under survey as all the crimes revealed by the table were geometrically doubled. Perhaps, this may be attributed to pre-election vices (gubernatorial election of Anambra took place in 2010) and increased quest for materialism. Equally, 2016 Crime Statistics of the State by National Bureau of Statistics indicated that crime is still in the increase in the state as they were among the first ten states in Nigeria with the highest crime rate. However, criminologists and social scientists generally, have observed that there is a significant gap or difference between official crime statistics and public perceptions and reality, that is, actual crime statistics (Inciardi, 2002). This is because crime is subject both to concealment and under-reporting with the result that official crime statistics fall significantly short of the full volume and range of offences. This means that crime statistics is just a minute percentage of the real situation (Elrena \& Ricky, 2008). By implication, therefore, in the case of Anambra State, the crime problem is much higher and prevalent than the official statistics would want us to believe. In response to the increasing vulnerability of Anambra State in armed robbery, kidnapping and other violent crimes, the Inspector General of Police drafted fifteen (15) units from Police Mobile Force (PMF) Squadrons and three (3) Operation Units of the Anti-Terrorist Squad (ATS) to the State Command to reduce violent crimes generally (Anambra State Police Command Annual Report, 2009; Anambra State Police Command Annual Report, 2010). In addition, the community vigilantes are increasingly being established and encouraged by the State government to assist the police in crime control and boost community security (Okoronkwo, 2011).

However, the rising crime rate, especially violent crimes involving armed robbery, ritual murders, political assassinations, kidnapping, ethnic and religious violence and election violence appear to have dampened the public's hope on the capacity of the police to ensure the safety of people's lives and property. The general feeling is that the police can neither solve the crime already committed through arrests and successful prosecutions, nor prevent or at least reduce, the incidence of crime in the Nigerian society. This feeling has led to public distrust of the police, apparent lack of confidence, hatred and suspicion, and the feeling of intimidation by police presence (Dambazau, 2009). The same source maintained that public perception of the police has been negative and that the Nigeria Police Force has been under intense scrutiny by the public they serve, and the reasons range from lack of professionalism, corruption, etc. which culminate in ineffectiveness and inefficiency of the police force in preventing and controlling crime, thus subjecting the Force to public criticism and ridicule. For Okereke (1993), many Nigerians perceive the policeman as a lazy, corrupt, inefficient, bribe-taking, and money extorting officer. This means that the Nigeria Police has a very serious image problem in the eyes of the public it is established to serve. Pollick (2011) maintained that public perception is not necessarily inaccurate or based on something other than truth. The public at large can often receive enough information to form a general opinion about an issue without relying on innuendo or unfounded rumors. He admitted, however, that there can be instances when public perception of a situation is affected by other issues, such as cultural bias or prejudice. However, the public now resorts to employing private security guards for security purposes, thus exhibiting their discontent and distrust with the men of the police force. The objectives of this study, among other things, will be to identify the most prevalent crimes in Nigeria today particularly, Anambra State, ascertain the views of the public on the effectiveness of the Nigerian Police Force in their statutory duty of crime control and find out the extent to which public co-operation and information inter-flow can facilitate better crime policing. This study focuses on the feelings and views of the public in Anambra State of Nigeria concerning the police performance in their statutory function of maintenance 
of law and order, particularly crime control.

\section{Research Hypotheses}

Drawing on the discussion above, four hypotheses guided the study:

H1: Educated people are more likely to have positive views on the effectiveness of the police in crime control than non-educated people

H2: There is significant relationship between the perception of urban residents and their rural counterparts on the promptness of the police to emergency cases

H3: There is significant difference between opinions of male and female respondents on the level of co-operation and information inter-flow between the police and the public.

\section{Materials and Methods}

\subsection{Study Area and Population}

This study was conducted in Anambra State. It is one of the five states in the South East geopolitical zone of Nigeria. Anambra State was created in 1976 from the then East Central State (by the regime of General Murtala Mohammed) with capital at Enugu. A further state creation exercise by the regime of General Ibrahim Babagida on 27th August 1991 carved Enugu State, out of Anambra State. Awka became the capital of the new Anambra State which is bounded by Delta and Edo States to the west, Imo and Rivers States to the south, Enugu State to the east and Kogi State to the north. Anambra State derived its name from Anambra River that traverses the state (NigeriaGalleria.Com, 2010). Per the National Population Commission (NPC, 2006), the population of Anambra State stood at four million, one hundred and eighty-two thousand and thirty-two $(4,182,032)$ people with an annual growth rate of $2.8 \%$. Anambra State has 21 local government areas (LGA) which are further divided into 330 political wards and approximately 1,394 communities. This study was limited to Anambra State of Nigeria and the reason being that it is a crime-prone area and among the ten states of Nigeria with the highest crime rate (National Bureau of Statistics, 2006).

\subsection{Sample Size and Sampling Procedure}

The target population for this study consisted of all adults from eighteen (18) years and above, which represents $57.5 \%$ of the total population (NPC, 2006). The focus on adult segment of the population was justified by the fact that at age eighteen (18), the individual is considered mature and reasonable to be liable and responsible for his words, actions and inactions, and equally can make sound judgment of any situation. Using Yaro Yamene formula (Okeke, 1995), a sample size of 624 was computed. The multistage sampling and random sampling techniques were adopted in selecting four (4) communities and/or towns in the State. Anambra State has main and minor towns and/or communities (NigeriaGalleria.Com 2010:2). So, the four (4) communities were chosen from the cluster, that is, two (2) from each of the two (main and minor). The data base of the State has given us the list of the main towns; others serve as the minor towns. Furthermore, simple random sampling technique was used to select villages within the communities chosen, to select the respondents. Each of the four communities and/or towns was given equal number of respondents, that is, one hundred and fifty-six (156) each. When this was done, the researcher used purposive and systematic sampling technique in choosing the respondents from the villages selected. In purposive sampling technique, there are always one or more predefined groups. For this work, the predefined group was adults $(18+)$ who are enlightened and well-informed. This category of people was determined not just by their dressing, but their responses in the exchange of pleasantries, and this ensured adequate information, accuracy and conciseness. Every $\mathrm{K}^{\text {th }}$ number in the list was systematically chosen. Out of the 624questionnaire distributed, 618 were successfully retrieved.

\subsection{Data Collection}

The main instrument used in collecting data for this study was the questionnaire. A list of pre-set questions was administered to respondents in the four communities. The questionnaire solicited information from the respondents who may have been both victims of crime and victims of police intervention in crime. It sought to know their socio-demographic backgrounds, whether the respondents have been victims of crime before or not, and if they have been whether they reported the incidents to police or not. The reaction and/or response of the police to their report were sought. Also included were questions on police-public cooperation, that is, whether respondents would be prepared to give evidence in court against suspected criminals, if they would be prepared to volunteer information to the police about any crimes and suspected criminals they know of, give evidence in court against suspected criminals, etc. 


\subsection{Data Analysis}

The study employed quantitative method of data analysis. The questionnaire was edited and coded using a carefully developed Code Book Data Entry, and analysis carried out using Statistical Package for Social Sciences (SPSS). Percentages and other descriptive statistics were used for statistical analysis. The Chi-Square $\left(\mathrm{X}^{2}\right)$ was used to test the hypotheses. Correlation analysis were also done using chi-square $\left(\mathrm{X}^{2}\right)$ to illustrate the relationship between certain socio-demographic variables and how the public perceives and can partner the police in their crime control duty.

\section{Results}

The table 2 below represents the socio-demographic characteristic information of the respondents who fielded the questionnaire, the data collection instrument for this research study. The responses from the 618 questionnaires successfully retrieved indicated that males were $50.0 \%$ of the respondents while the females also constituted $50 \%$ of the sample. The table shows that both sexes were equally represented in the sample and this aligns with the distribution of both genders in the 2006 Census Population of Anambra State, the area of the study projected to 2014. The highest number of respondents were aged between 26 and 39 years (36.2\%) followed by those aged 4055 years $(26.9 \%)$ and then those aged $18-25(25.9 \%)$. The least was the group aged 56 years and above $(11.0 \%)$.

Table 2: Socio-demographic Characteristics of Respondents

\begin{tabular}{|c|c|c|}
\hline Sex & Frequency & Percentage \\
\hline Male & 309 & 50.0 \\
\hline Female & 309 & 50.0 \\
\hline Total & 618 & 100.0 \\
\hline \multicolumn{3}{|l|}{ Age } \\
\hline $18-25$ & 160 & 25.9 \\
\hline $26-39$ & 224 & 36.2 \\
\hline $40-55$ & 166 & 26.9 \\
\hline 56-above & 68 & 11.0 \\
\hline Total & 618 & 100.0 \\
\hline \multicolumn{3}{|l|}{ Occupation } \\
\hline Civil servant & 74 & 12.0 \\
\hline Teacher/Lecturer & 136 & 22.0 \\
\hline Business & 101 & 16.3 \\
\hline Farming & 21 & 3.4 \\
\hline Student & 165 & 26.7 \\
\hline Trading & 46 & 7.4 \\
\hline Unemployed & 22 & 3.6 \\
\hline Artisan & 53 & 8.6 \\
\hline Total & 618 & 100.0 \\
\hline \multicolumn{3}{|c|}{ Educational qualification } \\
\hline No formal education & 20 & 3.2 \\
\hline Primary school & 57 & 9.2 \\
\hline Secondary school & 201 & 32.5 \\
\hline Tertiary school & 340 & 55.0 \\
\hline Total & 618 & 100.0 \\
\hline \multicolumn{3}{|l|}{ Place of residence } \\
\hline Urban & 311 & 53 \\
\hline Rural & 307 & 47 \\
\hline Total & 618 & 100.0 \\
\hline
\end{tabular}

Source: Field survey, 2017

On respondents' occupation, students and teachers/lecturers were more in number. Thus $26.7 \%$ of the people sampled were students while $22.0 \%$ belonged to the teaching profession. Businessmen/women constituted $16.3 \%$ of the respondents, civil servants $12.0 \%$, while less than ten percent $(8.6 \%)$ were artisans. Others were traders (7.4\%), unemployed (3.6\%) and farmers (3.4\%). Very few respondents $(3.2 \%)$ had no formal education. On the other hand, most the respondents $(55.0 \%)$ had tertiary education. Slightly less than one-third of the respondents $(32.5 \%)$ had up to secondary school education. Those with only primary education constituted less than ten percent of the respondents $(9.2 \%)$. The important finding here is that more than three quarters of the respondents $(96.7 \%)$ 
have had some form of formal education, implying that the communities appreciate the value of education and should be able to affect their environment positively. Respondents from urban areas, that is, the main communities (Nnewi and Nkpor) constitute $50.3 \%$ of the total respondents while those from rural areas, that is, the minor communities (Amawbia \& Oko) constitute 49.7\%. Both urban and rural dwellers are well represented and this will be of much value to us in the testing of hypotheses where the perception of both dwellers shall be compared on the promptness of the police to emergency cases. Three hypotheses formulated to guide this study were tested at this juncture at 0.05 level of significance. That is, if the level of significance is less than or equal to $(\leq) 0.05$, then there is a significant relationship.

Table 3 below reveals that the level of education of the respondents affects their rating of police effort in crime control. For instance, $70 \%$ of those with no formal education perceived the police as being trained adequately for the purposes of crime control while $68.4 \%, 54.7 \%$ and $49.1 \%$ of respondents with primary, secondary and tertiary education respectively also shared the same

Table 3: Educational Attainment and Views on Training of the Police to Confront Crime

\begin{tabular}{|c|c|c|c|c|c|}
\hline \multirow{2}{*}{$\begin{array}{l}\text { The Police being } \\
\text { trained to confront } \\
\text { challenges of crime } \\
\text { criminality }\end{array}$} & \multicolumn{4}{|c|}{ Educational Status } & \multirow[b]{2}{*}{ Total } \\
\hline & $\begin{array}{l}\text { No Formal } \\
\text { Education }\end{array}$ & $\begin{array}{l}\text { Primary } \\
\text { School } \\
\text { Education }\end{array}$ & $\begin{array}{l}\text { Secondary } \\
\text { School } \\
\text { Education }\end{array}$ & $\begin{array}{l}\text { Tertiary } \\
\text { Education }\end{array}$ & \\
\hline Yes & $14(70.0)$ & $39(68.4)$ & $110(54.7)$ & $167(49.1)$ & $330(53.4)$ \\
\hline No & $6(30)$ & $18(31.6)$ & $91(45.3)$ & $173(50.9)$ & $288(46.6)$ \\
\hline Total & $20(100.0)$ & $57(100.0)$ & $201(100.0)$ & $340(100.0)$ & $618(100.0)$ \\
\hline
\end{tabular}

$\mathrm{x}^{2}=10.031, \mathrm{df}=3, \mathrm{P}=0.018$

view. On the other hand, respondents with primary, secondary and tertiary education who think otherwise of the police in their statutory duty of crime control constitute $31.6 \%, 45.3 \%$ and $50.9 \%$ of their different categories respectively, while $30 \%$ of respondents with no formal education also believe that the efforts of the police in the face of the devastating crime situation is grossly insufficient.

When the data were subjected to a statistical test, the chi-square value of 10.031 was significant at 0.018 levels. This implied that there is a statistically significant relationship between education and the perception of police efforts in crime control. Therefore, hypothesis one is upheld.

Table 4: Percentage Distribution of Respondents by Community and Promptness of Police to Emergency Cases

\begin{tabular}{llll}
\hline \multirow{2}{*}{$\begin{array}{l}\text { Police reacting promptly to reported } \\
\text { emergency cases }\end{array}$} & \multicolumn{3}{c}{ Community } \\
\cline { 2 - 4 } & Urban & Rural & Total \\
\hline Yes & $80(25.6)$ & $121(39.5)$ & $201(32.5)$ \\
No & $232(74.4)$ & $185(60.5)$ & $417(67.5)$ \\
\hline Total & $\mathbf{3 1 2 ( 1 0 0 )}$ & $\mathbf{3 0 6}(\mathbf{1 0 0 . 0})$ & $\mathbf{6 1 8 ( 1 0 0 . 0 )}$ \\
\hline
\end{tabular}

$\mathrm{x}^{2}=13.604, \mathrm{df}=1, \mathrm{P}=.000$

Table 4 indicates that there is a difference between the thinking of urban residents and that of their rural counterparts on the promptness of the police to emergency cases. For instance, $25.6 \%$ of the urban residents think that the police respond promptly to emergency cases in their areas while $39.5 \%$ of those in the rural areas also think that the police respond promptly to emergency situations. On the other hand, $74.4 \%$ of urban residents think the police do not respond quickly to emergency cases while $60.5 \%$ of rural dwellers equally do not consider police as responding promptly to emergency cases. In all, it is important to note that more than half of the respondents both in urban and rural areas do not think the police respond promptly to emergency.

The chi-square value which is 13.604 was significant at .000 levels. This implied that there is a statistically significant relationship between place of residence and promptness of police to emergency cases. This calls for a rejection of the null hypothesis which holds that there is no relationship between place of residence and promptness of police to emergency cases. The conclusion here, going by the result of the test of hypothesis, that there is a significant relationship between the perception of urban residents and their rural counterparts on the promptness of the police to emergency cases is hereby upheld. 
However, the researchers probed further to ascertain the reasons for non-promptness of the police to emergency crime situations, and various reasons were given as demonstrated in table $\mathbf{4 . 1}$ below. The highest proportion $(39.1 \%)$ of the respondents was of the view that corruption is

Table 4.1: $\quad$ Distribution of Respondents on Reasons for non-promptness of the Police to Emergency Cases

\begin{tabular}{lll}
\hline Causes of Non-Promptness of the Police & Frequency & Percentage \\
\hline Corruption & 163 & 39.1 \\
Police not properly equipped & 80 & 19.2 \\
Lack of motivation and incentives & 19 & 4.6 \\
Negligence & 124 & 29.7 \\
Don't know & 31 & 7.4 \\
\hline Total & $\mathbf{4 1 7}$ & $\mathbf{1 0 0 . 0}$ \\
\hline
\end{tabular}

Source: Field Survey 2014

highly behind the not-too-good attitude of the police not responding promptly to reported emergency cases. About half $(48.9 \%)$ of the respondents were of the view that negligence $(29.7 \%)$ and not being properly equipped (19.2\%) respectively also contribute to non-promptness of the police, while less than five percent (4.6\%) of the respondents said the non-promptness of the police to reported cases can be traced to lack of motivation and incentives. The rest $(7.4 \%)$ declined that they do not know what may be the reasons or factors. The bottom line is that the police force does not respond promptly to reported emergency cases which amounts to ineffectiveness and inefficiency on the part of the Nigerian Police Force.

Table 5: Percentage Distribution of Respondents by Sex and the Public helping the Police in Controlling Crime

\begin{tabular}{lllll}
\hline $\begin{array}{l}\text { Public helping the } \\
\text { controlling Crime }\end{array}$ & Police in & \multicolumn{2}{c}{ Sex } & \\
& & \multicolumn{2}{c}{ Total } \\
\cline { 3 - 4 } & & Male & Female & $534(86.4)$ \\
\hline Yes & & $264(85.4)$ & $270(87.4)$ & $84(13.6)$ \\
No & $45(14.6)$ & $39(12.6)$ & $\mathbf{6 1 8 ( 1 0 0 . 0 )}$ \\
\hline Total & & $\mathbf{3 0 9 ( 1 0 0 . 0 )}$ & $\mathbf{3 0 9}(\mathbf{1 0 0 . 0})$ & \\
\hline
\end{tabular}

$\mathrm{x}^{2}=.496, \mathrm{df}=1, \mathrm{P}=.481$

Table 5 shows that the proportion of males $(85.4 \%)$ who think the public can help the police in controlling crime most probably, by cooperation and information interflow is almost the same with the percentage of females $(87.4 \%)$ who share the same view. On the other hand, the respondents who share contrary view on the public helping the police, among both male and female gender were minimally different, with males constituting $14.6 \%$ while females constituted $12.6 \%$. Obviously, there is no difference between the perception of males and that of their female counterparts on the level of cooperation and information interflow between the police and the public.

The chi-square value shows that the level of $\leq$ significance stood at .481 . This indicates that there is no statistically significant relationship between gender (male or female) and level of cooperation and information interflow between the police and the public. Hence, the null hypothesis which states that there is no relationship between the opinions of males and females on the level of cooperation and information interflow between the police and the public is upheld.

\section{Discussion}

This study affirms the unprecedented wave of crime and criminality in our society today, which is a confirmation that Nigeria really is grappling with crime problem. Anambra, the state under survey was found to be highly infested with criminality. The findings of this study indicate that the police, by their training, ought to be prompt, proactive and effective in their response to crime menace and situations, but the reverse is the case. This finding tarry with Onyeozili (2005), Adegoke (2014), Karimu (2014) and Ajayi and Longe (2015) whose studies showed that the police have not been effective and efficient in the discharge of their constitutional responsibility of fighting crime and criminality. Hence, Telep and Weisburd (2012) maintained that to increase effectiveness in addressing crime, the police should concentrate on strategies that are most successful such as hot spots policing, focused deterrence strategies, directed patrol, etc. and not problem oriented or reactive policing. 
The study further revealed that there is an appreciable degree of police presence in the area but without a commensurate impact, thus culminating into lack of confidence by the people in the crime control duty of the police, which automatically leads them to resorting to other forms or means of security, especially Vigilante. This finding is in consonance with Odekunle (2004), Ajayi (2014), and Onyeozili (2005) who insisted that "people's recourse to violence is symptomatic indication of lack of trust in government, and loss of confidence in the regular police to provide adequate security for lives and property in the society." However, it is pertinent to note here that most states (in Nigeria) now institutionalize Vigilante groups and their activities, Anambra State inclusive, thus giving the sense that there is an urgent need for the creation of State police.

The study also identified public cooperation and information interflow as a veritable instrument towards actualizing a secured society. In other words, public partnership should be encouraged and enhanced in the fight against the scourge of criminality, so that the public can always give vital information to the police about crime and criminals. This finding agrees with other studies such as Ajibade (2011) and Ajayi and Longe (2015). Bradford and Jackson (2016) also maintained that 'public cooperation is central to effective and equitable day-to-day police work, with clear majority of criminal offences becoming known to the police through being identified first by a member of the public.' (p.1)

Empirical evidence from the study also indicate that negligence, corruption, inadequacy of equipment, lack of incentives and motivation among other things are the major risk factors contributing to ineffectiveness, inefficiency and non-performance of the Police in their statutory duty of crime control. This finding is in concert with studies by Onyeozili (2005), Ajibade (2011) and Adegoke (2014) who found that corruption, lack of adequate arms and ammunitions, poor remuneration, inadequate manpower, etc. are some of the challenges of the police in curbing crime. Also, noteworthy at this point, is the submission of Alemika and Chukwuma (2003) that corruption and extortion have eaten deep into the very fabric of the Nigerian Police Force. They maintained that while other facets of the society are not free from these evils, they are most unacceptable and unsuitable among the police whose statutory duty is to eradicate crime. According to the same source, closely related to the problem of corruption and extortion is the incidence of collusion of some police officers with criminals, which is a dimension of corruption, resulting in increased insecurity and police inefficiency in tackling crime. Similarly, Inciardi (2002) and Samaha (1997) asserted that police corruption is a form of occupational crime in which the police misuse their authority for private gain. Okiro (2007) also aligned himself with this position when he said 'The Nigerian Police is not spared of this cankerworm of corruption as it has come to characterize the behavior of an average Policeman.' (p.7) Consequently, the image of the police is continually marred, and the police-public relationship adversely affected as also been showed by studies.

\section{Conclusion}

The study has identified the perception of the public on the unprecedented and highly sophisticated nature of crime and criminality in our Nigerian society today which constitutes a major source of concern and worry to all and sundry. This new trend of crime seems to have defied almost all known strategies, thus presenting itself as being insurmountable. The government cum security agencies seems to be harassed and helpless in the face of these security challenges. Anambra State, the place of study, has a fair share of this problem and so this research work sets out to find out how the public in Anambra State perceives the police, one of the foremost security agencies charged with the responsibility of maintaining internal law and order, in the face of the increasingly difficult crime wave in the society.

Conclusively, there is every need for the police to rise to the challenges of crime and criminality, and to the performance of their statutory obligation of maintaining law and order in the society. In other words, effectiveness and efficiency are highly required of the police to make their impact in the society tangible as there is no substitute to a more effective crime fighters and peacekeepers in the police agency. To actualize this, a few recommendations have been made by the study which includes but not limited to the following:

- Formulation and implementation of policies to restructure and reposition the Police Force in line with the core and salient objectives of the Force

- A more severe penalty or sanctions for culprits of violent crimes especially armed robbery, kidnapping and rape to serve as a strong deterrence

- Equally, the Police Force should of very paramount importance, redeem its image with the public by ensuring integrity in all its dealings, and recruiting only men and women with reasonably sound education and character 
- Efforts should be made by the Nigerian authorities to address the various structural, institutional and logistics obstacles besieging the Nigerian Police Force in the exercise of their duty

- Furthermore, the government should ensure the creation of adequate and more police presence with commensurate impact in our communities especially the rural ones. In the light of this, the creation of State and Local Governments' Police is encouraged to serve the purpose of making police presence more impactful, and since most crimes are localized

- Finally, government at all levels (Federal, State and Local), private enterprises inclusive, should embark on massive creation of relevant social and economic environment, and conditions and programs that will address the problems of employment, education and poverty.

\section{Acknowledgement}

The technical and scientific support of Prof. E. U. M. Igbo, a renowned Professor of Criminology, Department of Sociology and Anthropology, University of Nigeria, Nsukka to the design and execution of this study is highly acknowledged.

\section{References}

Adegoke N. (2014). The Nigerian police and the challenges of security in Nigeria. Review of Public Administration and Management. 3(6), 21-35. Available from: www.arabianjbmr.com [Accessed 27th June 2018].

Adekunle, A. (22 February 2018). 110 Yobe school girls not accounted for-yobe police boss. Lagos: Vanguard Newspaper Media Limited.

Ajayi, J. O. (2014). Public perception of the police and crime prevention in Nigeria. International Journal of Criminology and Sociological Theory. 7(3), 1-12. Available from: https://ijcst.journals.yorku.ca/2014.pdf [Accessed 19th June 2018].

Ajayi, J. O. \& Longe, O. (2015). Public perception of the police and crime prevention in Nigeria. British Journal of Education, Society and Behavioural Science. 6(2), 145-153. Available from: www.sciencedomain.org [Accessed 19th June 2018].

Ajibade, D. (2011). Crime prevention and control in Nigeria: A study of ogun state police command. African Journal of Law and Criminology. 1(1), 131-135. Available from: http://citeseerx.ist.psu.edu [Accessed 26th June 2018].

Alemika, E. (2012). Rethinking crime prevention and crime control approaches in Nigeria. Journal of the Nigerian Sociological Society. 2(1), 7-10.

Alemika, E. \& Chukwuma, I. (2003). Analysis of police and policing in Nigeria. Lagos: Clean Foundation. Available from: http://www.cleen.org/2013.pdf. [Accessed 7th January 2013].

Anyanwu, G., Mmadubueze, R. \& Onwuchekwa, D. (26 May 2010). 4 killed, 5 arrested, N6m recovered as armed robbers raid banks in Anambra. Lagos: Daily Sun Newspaper.

Anyanwu, G. \& Onuorah, I. (5 April 2012). Gunmen sack police station, free detainees, cart away 14 Ak47 rifles. Lagos: Daily Sun Newspaper.

Bradford, B. \& Jackson, J. (2016). Cooperating with the police as an act of social control - trust and neighbourhood concerns as predictors of public assistance. Available from: https://creativecommons.org [Accessed 24th April 2018].

Dambazau, A. (2007). Criminology and criminal justice. Ibadan: Spectrum Book Ltd. 
Dodsworth, F. (2007). Police and the prevention of crime. The British Journal of Criminology: An International Review of crime and society. 47(3), 439 - 442. Britain: Center for Crime and Justice Studies.

Elrena, V. S. \& Ricky, R. (2008). Police and crime prevention in africa: A brief appraisal of structures, policies and practices. International Centre for the Prevention of Crime. Available from: http://www-prevention-intl.org [Accessed 5th June 2015].

Federal Republic of Nigeria. (2010). 2006 Population and housing census. Abuja: National Population Commission.

Igbo, E. U. M. (2007). Introduction to criminology. Nsukka: University of Nigeria Press Ltd.

Inciardi, J. A. (2002). Criminal justice.7th ed. New York: Oxford University Press, Inc.

Karimu, O. O. (2014). Nigeria police force performance in Crime prevention and control: An assessment. International Journal of Academic Research and Reflection. 2(4), 81-88. Available from: www.idpublications.org [Accessed 28th July 2018].

Kola, O. \& Ajakaye, R. (4 January 2018). “Nigeria: Another chibok schoolgirl 'rescued”,. Available from: https://en.m.wikipedia.org [Accessed 9th May 2018].

National Bureau of Statistics. (2016). Crime statistics: Reported offences by type and state. Available from: http://www.nigerianstat.gov.ng [Accessed 4 April 2018].

NigeriaGalleria.Com. (19 March 2010). Nigeria information guide: Anambra state of nigeria. Available from: http://www.nigeriagalleria.com [Accessed 21st November 2011].

Nigeria Police Force. (2009). Anambra state annual report. Awka: State Police Command.

Nigeria Police Force. (2010). Anambra state annual report. Awka: State Police Command.

Nigeria Police Force. Anambra state crime statistics 2005 to 2010. Awka: State Police Command.

Nnaji, W. (1 March 2008). Nigeria television authority national news hour. Nigeria: Public Broadcasting Service.

Odekunle, F. (2004). Overview of policing in Nigeria: Problems and suggestions. In E.E.O. Alemika \& I.C. Chukwuma (Eds.), Crime and policing in Nigeria: Challenges and options (pp. 22-34). Lagos: Cleen Foundation 2004. Available from: www.academia.edu [Accessed 11th February 2019].

Okeke, A. (1995). Foundation statistics for business decisions. Enugu: High Mega System Limited.

Okereke, O. (1993). Public attitudes towards the police force in nigeria. Police Studies. 16(3), 113-121.

Okiro, M. (2007). State of the nigeria police force as at November 2007. Available from: http://www.nigeriapolice.org/-31k [Accessed 13th April 2009].

Okoronkwo, O. (21 July 2011). Federal radio cooperation of Nigeria national news hour. Nigeria: Public Broadcasting Service.

Onuorah, I. \& Ekpunobi, D. (6 April 2012). Anambra attacked again: Gunmen kill 3 cops, raze police station. Lagos: Daily Sun Newspaper.

Onyeozili, E. C. (2005). Obstacles to effective policing in Nigeria. African Journal of Criminology and Justice Studies. 1(1), 32-54. Available from: www.umes.edu.ajcjs [Accessed 21st November 2018].

Pollick, M. (2011). What is public perception? Available from: http://www.wisegeek.com. [Accessed 12th September 2011].

Samaha, J. (1997). Criminal justice. 4th ed. USA.: West Publishing Company. 
Telep, W. \& Weisburd, D. (2012). What is known about the effectiveness of police practices in reducing crime and disorder? Police Quarterly. XX (X), 1-27. Available from: http://pqx.sagepub.com [Accessed 24th April 2018].

Ugwuanyi, S. (2018). Offa bank robbery. Available from: http://dailypost.ng [Accessed 9 May 2018]. 